\title{
Süstalinable Chemistry\& Engineering

\section{Novel, Integrated Biorefinery Approach of Ceiba pentandra (Kapok) Seed and Its Secondary Waste}

\author{
Alfin Kurniawan, ${ }^{\dagger, \perp}$ Chintya Effendi, ${ }^{\dagger, \perp}$ Lu Ki Ong, ${ }^{\dagger, \perp}$ Yi-Hsu Ju, ${ }^{\dagger}$ Chun Xiang Lin, ${ }^{\S}$ \\ and Suryadi Ismadji ${ }^{* \dagger}$ \\ ${ }^{\dagger}$ Department of Chemical Engineering, Widya Mandala Surabaya Catholic University, Kalijudan 37, Surabaya 60114, Indonesia \\ ${ }^{\ddagger}$ Department of Chemical Engineering, National Taiwan University of Science and Technology, 43, Sec. 4, Keelung Road, Taipei 106, \\ Taiwan \\ ${ }^{\S}$ School of Chemical Engineering, The University of Queensland, St. Lucia, Brisbane, QLD 4072, Australia
}

\section{Supporting Information}

ABSTRACT: Total utilization of waste resources to harnessing energy based on the green engineering approach (biorefinery) is the main feature of this work. Kapok seed and its seed cake have been successfully transformed into renewable high-value products by the application of integrated biorefinery combining in situ subcritical methanol transesterification and pyrolysis processes. The in situ subcritical methanol transesterification of kapok seed into biodiesel was conducted at various temperatures $\left(120-180^{\circ} \mathrm{C}\right)$ and pressures $(2-3.5 \mathrm{MPa})$ for $2-8 \mathrm{~h}$ with a methanol/seed mass ratio of $24: 1$. The resulting seed cake was thermochemically converted to bio-oil and char via a slow pyrolysis process. The experiments were performed at five temperatures ranging from 300 to $700{ }^{\circ} \mathrm{C}$ within $2-4 \mathrm{~h}$ with two heating rates of 10 and $20{ }^{\circ} \mathrm{C} / \mathrm{min}$. The products namely biodiesel, bio-oil, and char all show suitable physicochemical properties as well as gross calorific value to be used as an alternative energy source displacing conventional petroleum fuel for industrial and transportation purposes.

KEYWORDS: Subcritical transesterification, Pyrolysis, Biodiesel, Bio-oil, Char, Green engineering process

\section{INTRODUCTION}

The intensive use of fossil fuels as an energy source is of great concern in this modern era where the transportation and industrial sectors are growing rapidly. The depleting reserves and related environmental issues have become the main reason for the seeking of renewable energy sources over the past decade. To this end, the biorefinery platform has been highlighted to address this worldwide issue through the transformation of biomass into fuels, power, and value-added chemicals. Such a concept resembles today's petroleum refineries and its application gives maximum profit from the integrated production of energy (electricity, heat, etc.) and multiple biobased products. As an agricultural country, Indonesia has many kinds of natural resources, and the application of an industrial biorefinery has opened the door for driving national economic growth, maintaining the sustainability of domestic energy reserves, and building new domestic biobased industries.

Currently, the liquid fuels that have drawn increasing attention are biodiesel and bio-oil. Biodiesel is a renewable fuel alternative for diesel engines, which is a mixture of long chain monoalkyl esters. Compared to fossil diesel fuel, biodiesel is more attractive due to its nontoxicity, biodegradability, safe handling and storage, cleaner engine emissions, and lubricating action on the engine. In addition, it can be blended with petrodiesel fuel at various proportions to make it compatible for direct use in the existing diesel engines and refueling stations with few or no modifications. ${ }^{1}$ Transesterification (or alcoholysis) is the common pathway for producing biodiesel from many kinds of vegetable oils and animal fats. The production of biodiesel via esterification or transesterification reactions can be catalyzed by liquid alkali and acid, ${ }^{2,3}$ enzyme, ${ }^{4}$ or solid catalysts. ${ }^{5,6}$ However, catalytic processes pose difficulties for the regeneration of spent catalyst, separation of the products, and treatment of wastewater. Moreover, transesterification catalyzed by liquid or solid alkali can only tolerate oil or lipid feedstocks with low content of free fatty acid (FFA) and water because soap formation prevents the separation of biodiesel from the mixture, decreases the effectiveness of the catalyst, and diminishes biodiesel yield. To account for these drawbacks, the subcritical and supercritical transesterification have been suggested as catalyst-free techniques for biodiesel production. ${ }^{7-11}$ Both of these techniques are able to convert fatty acid species into monoalkyl esters completely in shorter time than catalytic techniques and not sensitive to FFA and water contents in the feedstock. With respect to energy consumption, subcritical transesterification is less energy-consuming and easier to manage than the supercritical method. ${ }^{12}$ Besides,

Received: October 30, 2012

Revised: March 1, 2013

Published: March 4, 2013 
supercritical transesterification may pose technical constraints for practical applications because it requires high strength equipment to withstand high pressure and temperature in the process.

Bio-oil is one kind of valuable products obtained from the thermal cracking (pyrolysis) of biomass containing carbohydrate fibers such as cellulose, lignin, and hemicelluloses. ${ }^{13}$ In the pyrolysis process, the internal structure of the biomass is thermally decomposed without or with limited supply of oxygen that causes the structural fragmentations of large and complex moieties into simpler units. The resulting products consist of organic-rich liquid called bio-oil, carbon-rich solid called char, and noncondensable gases, which all have high economic values. Bio-oil can be used with or without an upgrading process for fueling some equipment such as boiler, burner, kiln, gas turbine, diesel engine, and furnace. ${ }^{14}$ The char can be utilized as a solid fuel, soil amendment, or bioadsorbent for the carbon capture to reduce $\mathrm{CO}_{x}$ emissions. ${ }^{15}$ The noncondensable gases (or syngas) that mainly composed of $\mathrm{CO}, \mathrm{CO}_{2}, \mathrm{H}_{2}$, and $\mathrm{CH}_{4}$ can be used as a heating media for the pyrolyzer system. ${ }^{13}$ Although a number of studies dealing with pyrolysis of biomass have been undertaken for a past decade, however, there is still a big gap in knowledge concerning the effects of biomass feedstock composition and processing parameters such as heating rate, final pyrolysis temperature, particle size, and residence time on the yield and quality of pyrolysis products. Furthermore, the seeking of alternative simple and green techniques for upgrading bio-oil to refined fuels is another gap in this area that needs to be addressed.

Kapok or silk-cotton tree (Ceiba pentandra) is a native plant from South America that belongs to Malvaceae family. This plant now widely distributed in the Southeast Asia region and occupies an important niche in the tropical rainforest ecosystem. The kapok tree produces silky cotton-like fiber from its seedpods. The fiber is often used as conventional filler for pillows, mattresses, and stuffed toys while the resulting seed ends up as a waste. The seed contains a fairly high amount of nonedible oil (around $40 \mathrm{wt} \%$, dry basis) with free fatty acid contents around $10 \mathrm{wt} \%$. The production of kapok seed in Indonesia reaches 115000 tons annually where half of them can be found in the East and Central Java provinces. Taking into account the abundance of underutilized kapok seed, the energy utilization of this biomass through the production of biofuels will be considered as a beneficial waste management process.

In this work, kapok seed is utilized as a raw material for the production of biofuels (biodiesel and bio-oil) and biobased product (char) based on the green engineering platform. The production of biodiesel is conducted via in situ subcritical methanol transesterification at various conditions. In this regard, methanol is purposely used and preferred over ethanol for conducting transesterification process because it is cheaper and more readily available than ethanol thus offering economic feasibility for the industrial-scale production. The effects of processing parameters such as pressure, temperature, and reaction time on the biodiesel yield are discussed. The application of an in situ subcritical transesterification method for biodiesel production offers several advantages such as the elimination of costly extraction stage, time saving compared to conventional and in situ catalyzed transesterification, and zero waste formation. To date, there is no available information regarding the noncatalytic biodiesel production from kapok seed via in situ subcritical methanol transesterification. The reported methods to transform kapok (or cottonseed) oil into biodiesel are transesterification catalyzed by acid, ${ }^{5}$ alkali, ${ }^{16,17}$ or enzyme ${ }^{18}$ and in situ alkaline transesterification. ${ }^{19}$ The resulting seed cake from the transesterification process still has an economic value; hence, it is further utilized to produce bio-oil and char via thermochemical conversion (pyrolysis). To the best of our knowledge, this is the first work demonstrating an integrated biorefinery which combines the in situ subcritical methanol transesterification and pyrolysis processes for the energy harnessing of kapok seed and its secondary waste through the formation of three sustainable products namely biodiesel, bio-oil, and char.

\section{MATERIALS AND METHODS}

Materials. Kapok seeds were obtained from Pati, Central Java, Indonesia. Prior to the use, the seeds were repeatedly washed with tap water to remove surface dirt, crushed, and sieved to obtain size fractions of $0.18-0.25 \mathrm{~mm}$. The initial moisture content of the seed was $10.6 \mathrm{wt} \%$, and it was reduced to about $2 \mathrm{wt} \%$ by oven-drying for $24 \mathrm{~h}$. The oil content in the dried seed was $39.43 \mathrm{wt} \%$, as determined by a Soxhlet extraction procedure following the AOAC Official Method 945.16. The free fatty acid (FFA) content was analyzed by titration against standardized $0.25 \mathrm{~N} \mathrm{KOH}$ solution following the ASTM D5555-95 method and is found to be $9.08 \mathrm{wt} \%$. The fatty acid composition was determined using a Shimadzu GC-2014 equipped with a flame ionization detector (FID). The stationary phase was a Restek Rtx-65TG fused silica capillary column $(30 \mathrm{~m} \times 0.25 \mathrm{~mm} \times$ $0.10 \mu \mathrm{m})$. The carrier gas was helium $(99.99 \%)$ at a constant linear velocity of $40 \mathrm{~cm} / \mathrm{s}$. The injection volume was $1 \mu \mathrm{L}$ with a split ratio of 1:40. The temperatures of the injector and detector were operated at $365{ }^{\circ} \mathrm{C}$. The temperature of the oven was set at $50^{\circ} \mathrm{C}$ for $1 \mathrm{~min}$ then elevated to $350{ }^{\circ} \mathrm{C}$ at $50{ }^{\circ} \mathrm{C} / \mathrm{min}$ and ramped at $1{ }^{\circ} \mathrm{C} / \mathrm{min}$ to $365{ }^{\circ} \mathrm{C}$ and held isothermally for $5 \mathrm{~min}$. The result shows that two major fatty acids (in triglyceride form) in kapok seed oil were linoleic acid $(42.18 \%)$ and oleic acid (33.23\%) with other fatty acids such as palmitic acid $(14.21 \%)$, stearic acid $(8.32 \%)$, and linolenic acid (1.46\%).

Analytical grade methanol, heptane, and anhydrous petroleum ether were purchased from Sigma Aldrich, Singapore. The reference standards used for the identification of fatty acid methyl ester (FAME) species were methyl palmitate, methyl stearate, methyl oleate, methyl linoleate, and methyl arachidate (99\%, Aldrich). Methyl heptadecanoate internal standard (99.5\%) was supplied by Fluka, Germany. Whatman filter paper no. 40 was used throughout all experiments.

In situ Subcritical Methanol Transesterification. The in situ subcritical methanol transesterification experiments were performed in a $150 \mathrm{~mL}$ custom-made high pressure batch reactor at pressures and temperatures ranging from 2 to $3.5 \mathrm{MPa}$ and 120 to $180{ }^{\circ} \mathrm{C}$, respectively. The reaction system consists of a K-type thermocouple, a pressure gauge, and an external electric heater. All the fittings and tubings are made from 316SS grade stainless steel (Swagelok). The maximum working pressure and temperature of the system are $10 \mathrm{MPa}$ and $200{ }^{\circ} \mathrm{C}$, respectively. A cylinder containing highly pure nitrogen $(99.99 \%)$ is connected to the reactor and used to pressurize the system while keeping the mixture in the liquid state.

The experimental procedure was described as follows: a known amount of methanol and kapok seed were introduced to the reactor to give a methanol/seed mass ratio of 24:1. The reactor was purged with a given amount of nitrogen to remove air and build a bit of pressure prior to heating. Eight M8 screws that are able to withstand maximum tensile force of 12.8 tons were used to tighten the reactor with its cap. The mixture was then heated at a rate of $20{ }^{\circ} \mathrm{C} / \mathrm{min}$ from room temperature to desired reaction temperatures $(120,140,160$, and 180 $\left.{ }^{\circ} \mathrm{C}\right)$. To maintain isothermal and isobaric conditions, the temperature was controlled by a PID-type controller with uncertainty of $\pm 1{ }^{\circ} \mathrm{C}$ and the pressure was monitored by a pressure gauge. Zero reaction time was defined when the temperature and pressure of the system reaches the set value. Then, the reaction was held for a prescribed time $(2,4,6$, 
and $8 \mathrm{~h}$ ). Subsequently, the reactor was immersed in a water-bath to quench the reaction immediately and depressurized to ambient pressure. The solid fraction (seed cake) was separated by vacuum filtration using a Buchner funnel. The seed cake was washed with distilled water three times, dried in an oven at $80{ }^{\circ} \mathrm{C}$ for $2 \mathrm{~h}$, crushed, and sieved through a 100/140 mesh screen. The liquid fraction was placed in a $250 \mathrm{~mL}$ separation funnel overnight for layer separation between biodiesel (fatty acid methyl ester) and glycerol. The fatty acid methyl ester-rich phase (top layer) was taken, and the residual methanol was removed by evaporation on an IKA RV-10 rotavapor at $80{ }^{\circ} \mathrm{C}$ for $2 \mathrm{~h}$.

Quantification of FAME Contents. The fatty acid methyl ester contents were analyzed on a Shimadzu GC-2014 equipped with a DBWax capillary column $(30 \mathrm{~m} \times 0.25 \mathrm{~mm} \times 0.25 \mu \mathrm{m})$ and a split/ splitless injector. Prior to the injection, the sample was filtered pass through a $0.22 \mu \mathrm{m}$ PVDF membrane and diluted with heptane. A certain amount of $0.1 \mathrm{~g} / \mathrm{mL}$ methyl heptadecanoate solution was added to the sample as an internal standard. The pretreated sample was taken using a microsyringe $(1 \mu \mathrm{L})$ and injected into the column in a splitless mode. The carrier gas was helium at a constant linear velocity of $40 \mathrm{~cm} / \mathrm{s}$. The temperature of the injector and detector was set at 250 and $300{ }^{\circ} \mathrm{C}$, respectively. The oven temperature was initially programmed at $50{ }^{\circ} \mathrm{C}$ for $2 \mathrm{~min}$ then ramped at $10{ }^{\circ} \mathrm{C} / \mathrm{min}$ to $250{ }^{\circ} \mathrm{C}$ and held for $8 \mathrm{~min}$. The fatty acid methyl ester components in the sample were identified by comparing retention time of the peaks to the reference standards. The yield of fatty acid methyl esters was calculated by the following equation: ${ }^{20}$

$$
\operatorname{FAME}(w t \%)=100 \times\left(\frac{\sum A_{\mathrm{ME}}-A_{\mathrm{int}}}{A_{\mathrm{int}}} \times \frac{V_{\mathrm{int}} C_{\mathrm{int}}}{m}\right)
$$

where $\sum A_{\mathrm{ME}}$ is the total peak area of fatty acid methyl esters, $A_{\mathrm{int}}$ is the peak area of methyl heptadecanoate internal standard, $V_{\text {int }}$ is the volume of methyl heptadecanoate solution added to the sample $(\mathrm{mL})$, $C_{\text {int }}$ is the concentration of methyl heptadecanoate solution $(\mathrm{g} / \mathrm{mL})$, and $m$ is the mass of kapok seed used $(\mathrm{g})$.

Characterizations of Kapok Seed Cake. Kapok seed cake (KSC) collected from in situ subcritical methanol transesterification experiments was further utilized as a raw material to produce bio-oil and char. The proximate analysis of KSC was performed following the ASTM E870-82 procedure, and the results are given as follows: fixed carbon (FC) of $26.14 \%$, volatile matters (VM) of $71.51 \%$, ash of $1.08 \%$, and moisture $(\mathrm{M})$ of $1.27 \%$. The elemental composition of KSC was found as follows: $\mathrm{C}$ of $45.7 \%, \mathrm{H}$ of $7.8 \%, \mathrm{~N}$ of $0.8 \%, \mathrm{~S}$ of $0.3 \%$, and $\mathrm{O}$ of $45.4 \%$ (measured by difference), as determined by a Perkin-Elmer 2400 CHNS/O elemental analyzer. Thermal behavior of the sample was characterized by thermogravimetric analysis (TGA) on a Mettler-Toledo TGA/DSC 1 STAR system using nitrogen as the carrier gas at heating and cooling rates of 10 and $50{ }^{\circ} \mathrm{C} / \mathrm{min}$, respectively.

Pyrolysis Experiments of KSC. Pyrolysis experiments of KSC were conducted in a fixed-bed stainless steel reactor system, as shown in Supporting Information Figure S1. The maximum working temperature of the reactor is $1000{ }^{\circ} \mathrm{C}$ at ambient pressure. Prior to biomass loading, nitrogen was flowed to the reactor for removing air. The reactor was heated from room temperature to desired operating temperatures $\left(300,400,500,600\right.$, and $\left.700{ }^{\circ} \mathrm{C}\right)$ at heating rates of 10 and $20{ }^{\circ} \mathrm{C} / \mathrm{min}$. The process was held for $2-4 \mathrm{~h}$ under $\mathrm{N}_{2}$ flow at a constant rate of $150 \mathrm{~mL} / \mathrm{min}$. Then, the reactor was cooled down to around $50{ }^{\circ} \mathrm{C}$, and the resultant char was removed from the vessel and stored in the desiccators. The condensate product of pyrolysis vapor was collected in a measuring cylinder and referred to as bio-oil. The yields of bio-oil and char were determined gravimetrically using an analytical mass balance (Precisa 3000D).

Characterizations of Bio-oil and Char. The physical and chemical properties of bio-oil were characterized in terms of gross calorific value (ASTM D240), $\mathrm{pH}$ (ASTM E70), pyrolyzed solid content (ASTM D7544), water content (ASTM E203), sulfur content (ASTM 4294), ash content (ASTM 482), density (ASTM D4052), viscosity (ASTM D445), pour point (ASTM D97), and flash point
(ASTM D93). The chemical composition of bio-oil was determined on a Shimadzu GCMS-QP2010 Ultra equipped with a DB-5 MS capillary column $(30 \mathrm{~m} \times 0.25 \mathrm{~mm} \times 0.25 \mu \mathrm{m})$ and mass selective detector (MSD). The sample was injected in split mode with a ratio of 1:10 under helium flow at $1.5 \mathrm{~mL} / \mathrm{min}$. The initial oven temperature was set at $60{ }^{\circ} \mathrm{C}$ for $3 \mathrm{~min}$ then ramped to $300{ }^{\circ} \mathrm{C}$ at $5{ }^{\circ} \mathrm{C} / \mathrm{min}$ and held for $10 \mathrm{~min}$. The temperatures of the ion source and interface of the detector were set at 200 and $240{ }^{\circ} \mathrm{C}$, respectively. Identification of components in bio-oil was conducted by comparing mass chromatogram of the sample with standard database from the National Institute of Standards and Technology (NIST).

The properties of char were analyzed in terms of gross calorific value (ASTM D5865) and elemental composition (proximate and ultimate analyses). The rank of char was determined according to ASTM D388 classifications. For reproducibility test, all experiments were replicated three times and the average results were used.

\section{RESULTS AND DISCUSSION}

In-situ Subcritical Methanol Transesterification. Transesterification and esterification are essentially a slow reaction in the absence of a catalyst. Given this, liquid/solid acid and alkaline catalysts are the most widely used catalysts for accelerating these reactions. ${ }^{21}$ In this context, the solid catalyst is preferred over liquid ones because it is cheaper, regenerable, and can be derived from a large variety of low cost materials such as clays ${ }^{6,22,23}$ and waste shells. ${ }^{24-26}$ However, the performance of solid catalyst cannot be compared to liquid catalyst due to poor solubility of the former in the mixture even under vigorous stirring. Apart from this, the catalytic ester/ transesterification techniques pose difficulties in the regeneration of spent catalyst and separation of the products from the mixture and generate substantial amounts of wastewater containing toxic chemicals from the washing stage.

On the other hand, esterification and transesterification at subcritical conditions are relatively fast reactions without involving any catalyst. This condition can be achieved by applying temperatures between the boiling and critical point of alcohol and moderate pressures that are sufficient to keep the mixture in the liquid state. Such a method will make the fluids become denser and their solvating power will reach those of liquid solvents. The increasing solvent density of methanol at elevated pressure would promote the conversion of triglycerides and free fatty acids into methyl esters, thus higher FAME yield would be obtained. Besides pressure, temperature also contributes a crucial role in enhancing the homogeneity of a methanol-oil mixture by lowering the dielectric constant $(\varepsilon)$ of methanol. ${ }^{27}$ In addition, the role of temperature may also relate to providing an energy source (heat) for inducing the formation of charged intermediate-catalysts $\left(\mathrm{H}^{+}\right.$and $\mathrm{OH}^{-}$ions $)$from the dissociation of water molecules.

The source of water in the mixture may arise from the esterification of free fatty acid and initial moisture content in the feedstock and is necessary for conducting the reaction. During the process, the combined effects of pressure and temperature will turn liquid water into subcritical water that acts as an effective acid-base catalyst for the hydrolysis of triglycerides and methanolysis of free fatty acid into methyl ester. The mechanism of these reactions under subcritical conditions may be similar to that of acid-catalyzed esterification and transesterification. ${ }^{12}$ However, it should be kept in mind that too much water in the system (about $80 \mathrm{wt} \%$ ) is undesirable because it promotes the formation of carboxylic acids due to the reaction between the carbocation-II intermediate of protonated acyglycerides and water. ${ }^{28}$ This 

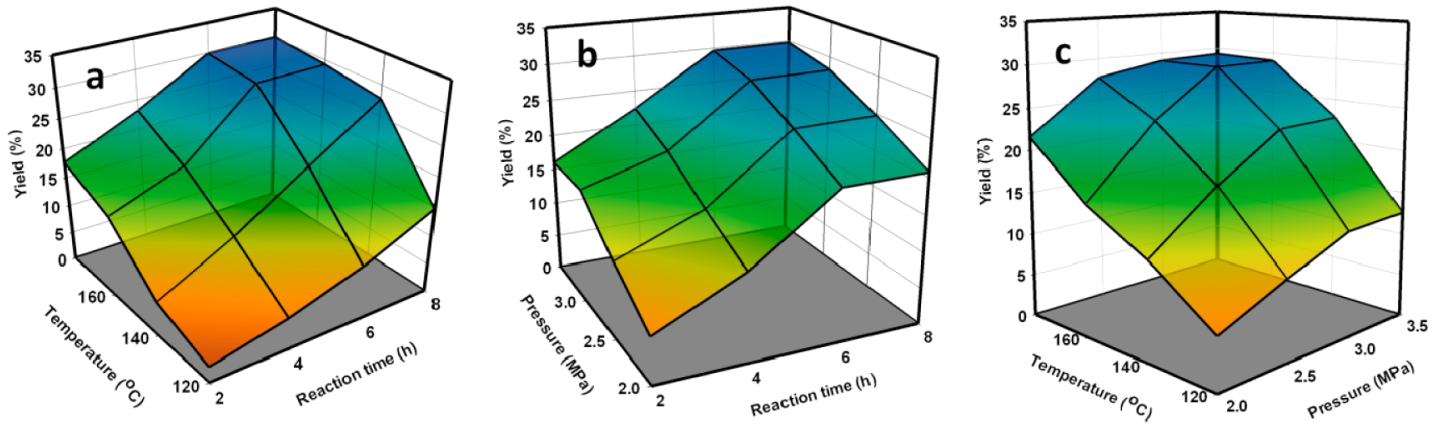

Figure 1. Experimental yield of biodiesel with variations of temperature and time at $3 \mathrm{MPa}$ (a), pressure and time at $160{ }^{\circ} \mathrm{C}(\mathrm{b})$, and temperature and pressure for reaction time of $6 \mathrm{~h}(\mathrm{c})$.

Table 1. Comparison of Several Transesterification Processes for the Production of Biodiesel from Kapok (Or Cottonseed) Oil

\begin{tabular}{|c|c|c|c|c|c|c|c|}
\hline \multirow[b]{2}{*}{ transesterification method } & \multicolumn{5}{|c|}{ reaction parameters } & \multirow[b]{2}{*}{ yield $(\%)^{c}$} & \multirow[b]{2}{*}{ ref } \\
\hline & alcohol/feedstock ${ }^{a}$ & wt $\%$ catalyst $^{b}$ & $P(\mathrm{MPa})$ & $T\left({ }^{\circ} \mathrm{C}\right)$ & time $(\mathrm{h})$ & & \\
\hline asphalt-based-catalyzed & 18.2 & 0.2 & 0.1 & 260 & 3 & 89.93 & 5 \\
\hline $\mathrm{NaOH}$-catalyzed & 0.21 & 1.5 & 0.1 & 50 & 1.5 & 98 & 16 \\
\hline $\mathrm{CH}_{3} \mathrm{ONa}$-catalyzed & 0.2 & 0.5 & 0.1 & $55-60$ & 24 & 77 & 17 \\
\hline Novozyme 435-catalyzed & 0.85 & 1.7 & 0.1 & 50 & 24 & 97 & 18 \\
\hline In-situ alkaline-catalyzed & $135: 1$ & 0.1 & 0.1 & 40 & 3 & 98 & 19 \\
\hline In-situ subcritical & $24: 1$ & none & 3 & 160 & 6 & 76.26 & this study \\
\hline
\end{tabular}

${ }^{a}$ Molar ratio (refs 5 and 19.), mass ratio (ref 18 and this study), and volume ratio (refs 16 and 17.). For ref 18 , the mixture consists of $32.5 \% t$ butanol, $13.5 \%$ methanol, and $54 \%$ oil. ${ }^{b}$ Based on the weight of oil (refs 5, 16, and 18), in $20 \%$ methanol (ref 17 ), and molar concentration in methanol (ref 19). ${ }^{c}$ Based on the weight of oil, the yield was $97.02 \%$ and $30.07 \%$ per gram of seed used for ref 19 and this study, respectively.

phenomenon reduces the conversion efficiency of triglycerides into methyl esters during the reaction and produces poor quality biodiesel with a low heating value.

While the presence of water at relatively small amount is essential for achieving high conversion reaction and avoids the formation of carboxylic acid, subcritical methanol plays dual roles during the process: (i) an extracting agent of oil and (ii) reacting alcohol. Unlike the poor extractability of oil by liquid methanol at ambient conditions due to the dissimilarity in polarity between the two components, the extraction performance of oil by subcritical methanol is superior. This can be explained by considering that the polarity of methanol at the subcritical phase is lower than that at the liquid phase due to decreasing strength of hydrogen bonding with increasing temperature, typically above the boiling point of methanol $\left(64.7^{\circ} \mathrm{C}\right)$. As a result, methanol becomes a nonpolar-like solvent at subcritical conditions that is able to extract oil from the seed matrix effectively. With respect to the methyl ester formation, an excess amount of methanol is required to shift the chemical equilibrium to the right-hand side. Therefore, a methanol to seed mass ratio of 24:1 was purposely used in this work not only to provide pressure for generating subcritical methanol phase but also ensuring high productivity of FAME.

Figure 1 shows the experimental trends of FAME yield that incorporates two-parameter interaction. It can be seen that temperature, pressure, and reaction time all play important roles toward the formation of fatty acid methyl esters. The effects of temperature may strongly relate to the chemical kinetics and decreasing the polarity of methanol in the mixture. The increase of temperature would promote the formation of methyl esters due to greater kinetic energy in the system that causes triglyceride and methanol molecules to collide more frequently. The accelerated formation rate of methyl esters at higher temperature is also attributed to the reduced polarity of methanol and viscosity of the oil that facilitates the formation of a single phase methanol-oil mixture. The effect of reaction time may be attributed to the contact duration between methanol and oil to form methyl esters. As displayed in Figure $1 \mathrm{~A}$, the yield of methyl esters per mass of kapok seed used increases from $2.74 \%$ and $5.94 \%$ to $17.64 \%$ and $25.12 \%$ by lengthening reaction time from $2-8 \mathrm{~h}$ at temperatures of 120 and $140{ }^{\circ} \mathrm{C}$ while maintaining the pressure at $3 \mathrm{MPa}$. However, a slightly different trend was observed at temperatures of 160 and $180{ }^{\circ} \mathrm{C}$ in which the increase in FAME yields was appreciably noted within a reaction time of $2-6 \mathrm{~h}$; then, it tends to remain constant at reaction times longer than $6 \mathrm{~h}$ (indicated by a fairly flat plot area). This might denote that the conversion of triglycerides and free fatty acids into methyl esters has reached a saturation point at an applied pressure and temperature. A similar trend was found in Figure $1 \mathrm{~B}$ that describes the trend of experimental FAME yield as a function of pressure and reaction time at a constant temperature of $160{ }^{\circ} \mathrm{C}$. When the pressure was increased from 2 to $3 \mathrm{MPa}$, a significant increase in FAME yield from $6.4 \%$ to $16.0 \%$ was noticed, possibly due to the enhanced miscibility of methanol in the oil phase. In this figure, the equilibrium reaction condition was established in $6 \mathrm{~h}$ for all pressures.

Figure $1 \mathrm{~A}$ and $\mathrm{C}$ reveals that the effect of temperature is more decisive than reaction time and pressure to the extent of FAME formation. A plausible explanation to this point is that temperature not only contributed to reducing the polarity of methanol but was also responsible for the formation of radical catalysts from the dissociation of water molecules. Moreover, high temperature also serves as an energy source (heat) for the system to surpass the activation barrier of esterification and transesterification reactions. The effect of pressure may cooperate with temperature for tuning the miscibility of methanol in the oil phase as in the case of supercritical 

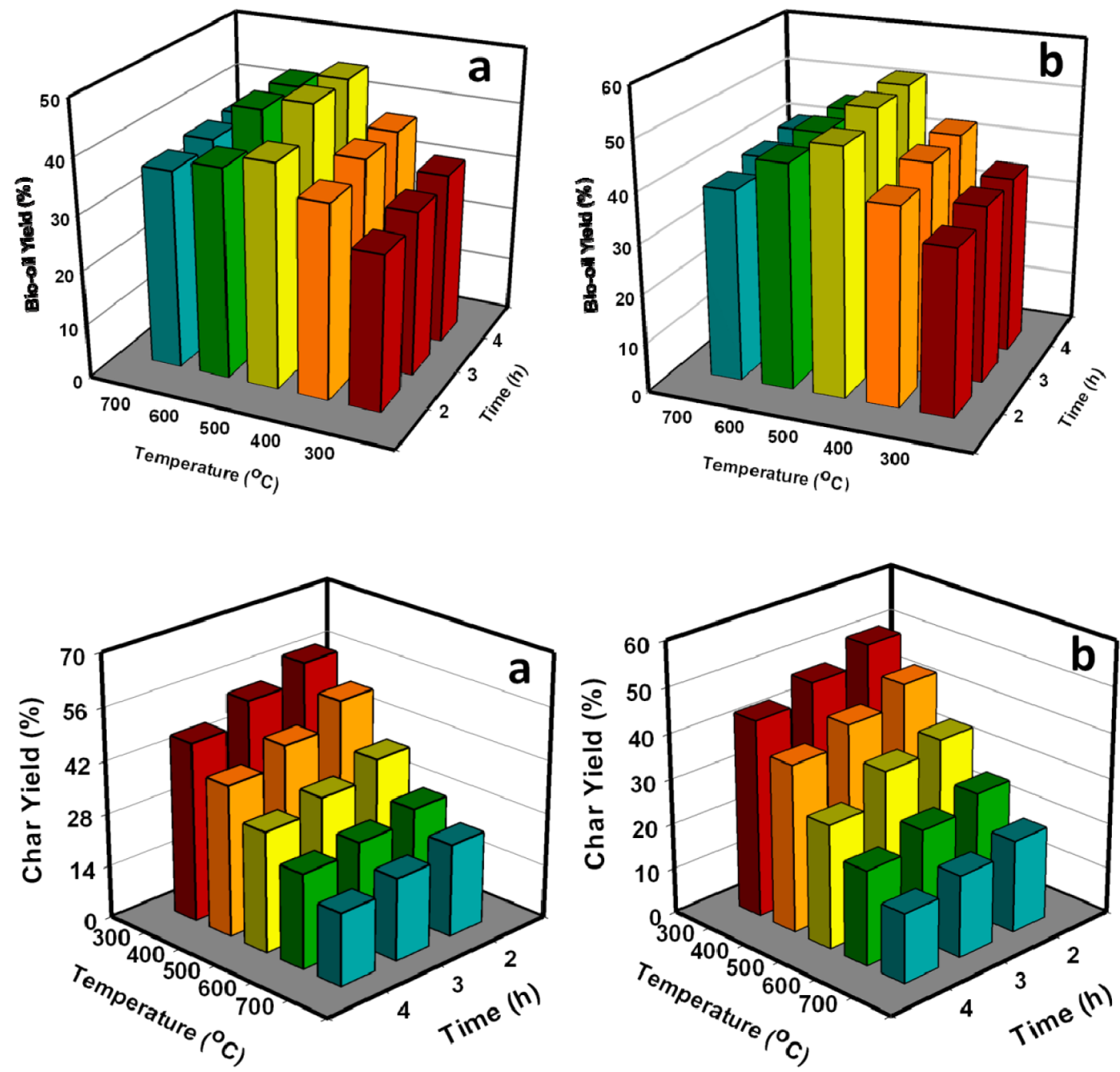

Figure 2. Experimental yield of bio-oil (top) and char (bottom) obtained at heating rates of 10 (a) and $20{ }^{\circ} \mathrm{C} / \mathrm{min}$ (b).

Table 2. Distribution of Major Organic Compounds in Bio-oil at Various Temperatures

\begin{tabular}{cccccccccc} 
& \multicolumn{8}{c}{ peak area $(\%)$} \\
\cline { 3 - 9 } heating rate $\left({ }^{\circ} \mathrm{C} / \mathrm{min}\right)$ & $T\left({ }^{\circ} \mathrm{C}\right)$ & alcohols & phenols & acids & esters & ketones & hydrocarbons & aldehydes & aromatics \\
\hline 10 & 300 & 10.41 & 11.18 & 25.06 & 9.63 & 3.04 & 4.48 & 7.23 & 2.72 \\
& 400 & 7.94 & 9.52 & 22.37 & 9.51 & 2.86 & 6.23 & 7.12 & 5.06 \\
& 500 & 2.23 & 7.66 & 18.24 & 7.44 & 2.48 & 10.17 & 5.91 & 7.81 \\
& 600 & 0.72 & 7.47 & 15.11 & 7.05 & 1.67 & 13.62 & 5.08 & 11.23 \\
20 & 700 & 0.05 & 7.09 & 13.68 & 6.92 & 1.73 & 15.41 & 4.74 & 14.46 \\
& 300 & 13.07 & 14.17 & 28.43 & 11.07 & 3.72 & 6.24 & 8.07 & 4.31 \\
& 400 & 10.61 & 13.26 & 25.02 & 10.14 & 3.44 & 9.06 & 7.51 & 7.42 \\
& 500 & 3.29 & 12.51 & 21.64 & 9.66 & 3.51 & 15.48 & 6.86 & 12.54 \\
& 600 & 1.87 & 12.02 & 18.22 & 9.52 & 3.06 & 18.12 & 5.44 & 15.02 \\
& 700 & 0.52 & 10.64 & 15.37 & 7.91 & 2.28 & 20.33 & 5.22 & 17.16 \\
\end{tabular}

transesterification. The highest yield of fatty acid methyl ester per mass of kapok seed was $30.07 \%$ (or $76.26 \%$ based on the weight of oil) that produced from in situ subcritical methanol transesterification at $160{ }^{\circ} \mathrm{C}$ and $3 \mathrm{MPa}$ for $6 \mathrm{~h}$. As a comparison, several transesterification methods and the optimized reaction conditions for biodiesel production from cottonseed oil are listed in Table 1. With respect to FAME yield, it can be confirmed that the in situ subcritical methanol transesterification method has a comparable performance to that of $\mathrm{CH}_{3} \mathrm{ONa}$-catalyzed transesterification conducted by
Nabi and co-workers. ${ }^{17}$ However, a lower FAME yield was observed in this work compared to that obtained by Qian et al. ${ }^{19}$ that conducting in situ alkali-catalyzed methanol transesterification. This might be ascribed to the lower conversion efficiency of triglycerides into methyl esters, mainly attributed to the insufficient amount of methanol for completely ester/ transesterifying fatty acids in the mixture. Additionally, the higher FAME yield obtained in the work of Qian et al. ${ }^{19}$ was likely due to the presence of catalytic action and a highly excessive molar ratio of methanol to oil used in the process. 
The fuel properties of kapok seed biodiesel (KSB) obtained at the above conditions are presented in Table S1. It can be seen that all properties of biodiesel fulfill the ASTM D6751 standard. The cetane number of KSB was 58, which is higher than the cetane index range of petro-diesel fuel reported in ASTM D975. This result implies that KSB has a shorter ignition delay period than petro-diesel fuel thus a better combustion performance. The kinematic viscosity of KSB also falls in the range of ASTM specification and is comparable to that of petrodiesel, indicating the compatible use of this fuel in the conventional diesel engines without any extensive modification.

Effects of Pyrolysis Processing Parameters on the Yield of Products. The effects of heating rate, pyrolysis temperature, and residence time on the yield of bio-oil and char are displayed in Figure 2. In this figure, it can be seen that the yield of bio-oil gradually increases with increasing temperature from 300 to $500{ }^{\circ} \mathrm{C}$, from $31.64 \%$ to $46.12 \%$ for a heating rate of $10^{\circ} \mathrm{C} / \mathrm{min}$, and from $36.71 \%$ to $52.57 \%$ for a heating rate of $20{ }^{\circ} \mathrm{C} / \mathrm{min}$. Apparently, the effect of pyrolysis temperature is more crucial than residence time toward the production of biooil. This can be explained by considering that increasing temperature will improve the conversion efficiency of the cracking reactions because extra energy input is available to break down the chemical bonds within the biomass structure. Table 2 contains the distribution of organic compounds in biooil at various temperatures. The resultant bio-oil at low pyrolysis temperature $\left(300{ }^{\circ} \mathrm{C}\right)$ mainly composed of alcohols, phenols, and carboxylic acids with minor concentration of ketones, aldehydes, esters, and aromatics. As temperature increased, the concentration of alcohols, phenols, and carboxylic acids progressively diminish while the concentration of aromatics and hydrocarbons starts mounting. This may be attributed to the greater extent of disorientation and structural fragmentation of the biomass and its derived functional groups at higher temperature that causes the evolution of various kinds of more stable species. ${ }^{29}$ Zhang et al. $^{30}$ and Horne and Williams $^{31}$ also reported a similar dependency on the organic distributions in bio-oil with temperature variation. Generally speaking, higher pyrolysis temperature leads to the decreasing concentration of the oxygenated groups in bio-oil, mainly attributed to the decarboxylation and secondary thermal cracking reactions.

The peak pyrolysis temperature of liquid yield was observed at $500{ }^{\circ} \mathrm{C}$ irrespective of the variation of heating rates. At this temperature, the yield of bio-oil reaches its maximum of about $46 \%$ and $52 \%$ for heating rate of 10 and $20{ }^{\circ} \mathrm{C} / \mathrm{min}$, respectively. This result agreed well with those reported in several studies, associated with the peak temperature for maximizing the liquid yield that ranged between 400 and 550 ${ }^{\circ} \mathrm{C}$. For example, Wang et al. $^{32}$ and Sukiran et al. ${ }^{33}$ obtained maximum liquid yields of $25 \%$ and $42.28 \%$ from the pyrolysis of lignocellulose fermentation residue at $475{ }^{\circ} \mathrm{C}$ and empty fruit bunch of oil palm at $500{ }^{\circ} \mathrm{C}$, respectively. A further increase in temperatures above $500{ }^{\circ} \mathrm{C}$ would diminish the liquid yield from $46.12 \%$ to $43.56 \%$ for a heating rate of $10{ }^{\circ} \mathrm{C} / \mathrm{min}$ and from $52.57 \%$ to $42.19 \%$ for a heating rate of $20{ }^{\circ} \mathrm{C} / \mathrm{min}$. This might be due to the secondary cracking of condensable hot volatiles and some organics in the tar product, which are the precursor for gases such as furfural, hydroxymethylfurfural, hydroxyacetone, hydroxyacetaldehydes, and glyceraldehydes. ${ }^{34}$ This phenomenon leads to the increasing yield of the gas product, mainly attributed to the vapor decomposition occurring at temperatures around $600{ }^{\circ} \mathrm{C}$.
The effect of heating rate may be of relevance to the thermal cracking rate that is responsible for determining the type and yield of the decomposition products. In this context, a slow heating rate is preferred when solid (char) is the primary product because a slow heating rate encourages the carbonization (or charring) of the biomass at a certain temperature and residence time. For liquefaction purposes, high heating rates are suggested because it causes a rapid structural decomposition that promotes the evolution of volatiles. Furthermore, high heating rates also diminish heat and mass transfer resistances and minimize the time available for secondary cracking reactions such as tar cracking and repolymerization. As depicted in Figure $2 \mathrm{~A}$ and B (top), an increase in heating rate enhances the yield of bio-oil, from $46.12 \%$ at $10{ }^{\circ} \mathrm{C} / \mathrm{min}$ to $52.57 \%$ at $20{ }^{\circ} \mathrm{C} / \mathrm{min}$ for a residence time of $4 \mathrm{~h}$ and pyrolysis temperature of $500{ }^{\circ} \mathrm{C}$. Demiral and Ayan $^{35}$ and Gercel $^{36}$ also reported similar trends of the liquid yield with variation of heating rates. The formation of noncondensable gaseous components consisting of $\mathrm{H}_{2}, \mathrm{CO}$, $\mathrm{CO}_{2}$, and $\mathrm{CH}_{4}$ strongly depends on the gas sweeping rate for purging hot volatiles out from the pyrolysis zone and the extent of cooling. In order to maximize the liquid yield, a combination of fast purging and rapid cooling of hot volatiles should be applied.

Regarding the char quality, longer residence time is necessary for producing char with high fixed and total carbon contents. On the other hand, the vapor residence time in the pyrolysis zone should be relatively short, but to a certain extent, in order to achieve high conversion efficiency and to prevent secondary cracking or repolymerization that degrades the yield of bio-oil and its quality. Figure $2 \mathrm{~A}$ and B (top) displays a similar experimental trend of bio-oil yield with residence time as those of temperature and heating rate. As expected, the role of residence time is less significant than temperature toward the formation of bio-oil since no appreciable increase in bio-oil yield was noticed by lengthening the residence time from 2 to 4 $\mathrm{h}$ for heating rates of 10 and $20{ }^{\circ} \mathrm{C} / \mathrm{min}$, respectively. Meanwhile, the char yield was strongly affected by temperature and residence time to a lesser extent, as shown in Figure 2A and B (bottom). On the basis of the experimental results, the optimum condition for pyrolyzing kapok seed cake that gives maximum yield of bio-oil (52.31\%) and a fairly high amount of char $(34.15 \%)$ is as follows: heating rate of $20{ }^{\circ} \mathrm{C} / \mathrm{min}$, temperature of $500{ }^{\circ} \mathrm{C}$, and residence time of $3 \mathrm{~h}$.

The thermal behavior of the biomass can be studied by monitoring the rate of weight loss as a function of temperature and time, often known as thermogravimetric analysis (Figure S2 of the Supporting Information). In the initial heating zone between 100 and $200{ }^{\circ} \mathrm{C}$, around $10 \%$ loss in the solid weight was observed, likely due to the removal of physically bound water and entrapped methanol from the seed cake matrix. A drastic weight loss of solid about $50 \%$ is identified at a temperature range of $200-700{ }^{\circ} \mathrm{C}$, which is the active pyrolysis zone. This may be attributed to the thermal cracking of the biomass that generates substantial amounts of volatiles and free radicals. ${ }^{37}$ These free radicals also contribute a lessening effect to break down the chemical bonds within biomass structure. ${ }^{13}$ Moreover, several reactions such as decarboxylation and primary and secondary crackings may also occur in the active pyrolysis zone that produces noncondensable gases, mainly $\mathrm{CO}$ and $\mathrm{CO}_{2}$. Toward the end of the heating zone $\left(700-900{ }^{\circ} \mathrm{C}\right.$ ), the weight loss of solid was insignificant since only fixed carbon and inorganic matters (ash) were left. 
Physicochemical Properties and the Quality Assessment of Bio-oil and Char. The physicochemical properties of bio-oil obtained from slow pyrolysis of KSC at the optimum conditions are given in Supporting Information Table S2. The gross calorific value of bio-oil was $18.7 \mathrm{MJ} / \mathrm{kg}$, which is higher than the ASTM D7544 requirement. This result confirms the appropriateness of this liquid fuel to displace the use of heavy or light fuel oils for fueling some industrial equipment such as boilers, kilns, gas turbines, etc. With respect to the pyrolysis solids and ash contents, the resulting bio-oil belongs to grade $\mathrm{G}$ according to the ASTM D7544 classification. The chemical composition of bio-oil determined from the GC-MS technique is listed in Supporting Information Table S3. The results show that the majority of organic groups in bio-oil are aromatics (12.54\%), hydrocarbons (15.48\%), phenols (12.51\%), and carboxylic acids $(21.64 \%)$ that comprise about $62 \%$ of bulk content of the product.

Supporting Information Table S4 shows the characteristics of chars obtained from slow pyrolysis of KSC at various temperatures. It was found that the rank of chars varies from high volatile $\mathrm{C}$ bituminous coal $(\mathrm{hvCb})$ to medium volatile bituminous coal (mvb) with respect to its fixed carbon and volatiles contents (dry and ash-free basis) and gross heat of combustion (moist and ash-free basis) based on the ASTM D388 classification. The gross heat of combustion of char ranges between 26.5 and $33.9 \mathrm{MJ} / \mathrm{kg}$, indicating the compatibility of this material to be used directly or mixed with other solid fuels for generating heat and power in the conventional power plants. In addition, low ash and sulfur contents are other beneficial properties of char, associated with $\mathrm{NO}_{x^{-}}$and $\mathrm{SO}_{x}$-free emissions. For soil amendment purposes, the char produced from slow pyrolysis of kapok seed cake at $700{ }^{\circ} \mathrm{C}$ with a heating rate of $20{ }^{\circ} \mathrm{C} / \mathrm{min}$ is the most suitable one, owing to the highest fixed carbon content $(57.5 \%)$ that results in greater stability and longer residence time in the soil. However, further studies on this area still need to be undertaken because the stability of biochar and the rate of labile/unstable carbon loss not only depends on the char properties (fixed carbon) but also on the soil condition.

\section{CONCLUSIONS}

An integrated energy utilization of kapok seed and its secondary waste through the production of liquid biofuels and char based on the biorefinery platform has been successfully applied in this work. The underutilized kapok seed was converted to biodiesel via a noncatalytic in situ subcritical methanol transesterification process. This relatively new technique has a comparable performance to that of catalyzed-transesterification to produce a fairly high FAME yield at moderate conditions. In this regard, temperature is plotted as the most decisive parameter to the extent of FAME formation. Thermochemical conversion of kapok seed cake via a slow pyrolysis process reveals that the production of bio-oil is more dependent on the final pyrolysis temperature and heating rate rather than the residence time. Experimental results show that the yield of bio-oil increases at higher heating rate and pyrolysis temperatures up to $500{ }^{\circ} \mathrm{C}$. Beyond the peak pyrolysis temperature $\left(500{ }^{\circ} \mathrm{C}\right)$, the yield of bio-oil starts declining, mainly attributed to the secondary thermal cracking. The highest yields of biodiesel, bio-oil (as the primary pyrolysis product), and char were $76.26 \%, 52.31 \%$, and $34.15 \%$, respectively. This work highlights the applicability of integrated biorefinery of kapok seed and its secondary waste that produces three sustainable products namely biodiesel, biooil, and char to meet a green engineering approach.

\section{ASSOCIATED CONTENT}

\section{Supporting Information}

Properties of biodiesel and bio-oil, chemical composition of bio-oil, characteristics of char, schematic of fixed-bed pyrolysis reactor, and TGA result. This information is available free of charge via the Internet at http://pubs.acs.org/.

\section{AUTHOR INFORMATION}

\section{Corresponding Author}

*E-mail: suryadiismadji@yahoo.com. Tel.: +62 313891264. Fax: +62 313891267 .

\section{Author Contributions}

${ }^{\perp}$ A.K., C.E., and L.K.O. contributed equally to this work Notes

The authors declare no competing financial interest.

\section{REFERENCES}

(1) Siddiquee, M. N.; Rohani, S. Lipid extraction and biodiesel production from municipal sewage sludges: A review. Renew. Sustain. Energy Rev. 2011, 15 (2), 1067-1072.

(2) Zhang, Y.; Dube, M. A.; McLean, D. D.; Kates, M. Biodiesel production from waste cooking oil: Process design and technological assessment. Bioresour. Technol. 2003, 89 (1), 1-16.

(3) Liu, Y.; Lotero, E.; Goodwin, J. G., Jr. Effect of water on sulfuric acid catalyzed esterification. J. Mol. Catal. A: Chem. 2006, 245 (1-2), $132-140$.

(4) Noureddini, H.; Gao, X.; Philkana, R. S. Immobilized Pseudomonas cepacia lipase for biodiesel fuel production from soybean oil. Bioresour. Technol. 2005, 96 (7), 769-777.

(5) Shu, Q.; Zhang, Q.; Xu, G.; Nawaz, Z.; Wang, D.; Wang, J. Synthesis of biodiesel from cottonseed oil and methanol using a carbon-based solid acid catalyst. Fuel Process. Technol. 2009, 90 (7-8), $1002-1008$

(6) Soetaredjo, F. E.; Ayucitra, A.; Ismadji, S.; Maukar, A. L. KOH/ bentonite catalysts for transesterification of palm oil to biodiesel. Appl. Clay Sci. 2011, 53 (2), 341-346.

(7) Demirbas, A. Biodiesel from vegetable oils via transesterification in supercritical methanol. Energy Convers. Manage. 2002, 43 (17), 2349-2356.

(8) Encinar, J. M.; Pardal, A.; Martinez, G. Transesterification of rapeseed oil in subcritical methanol conditions. Fuel Process. Technol. 2012, 94 (1), 40-46.

(9) Wang, L.; He, H.; Xie, Z.; Yang, J.; Zhu, S. Transesterification of the crude oil of rapeseed with $\mathrm{NaOH}$ in supercritical and subcritical methanol. Fuel Process. Technol. 2007, 88 (5), 477-481.

(10) Saka, S.; Kusdiana, D.; Minami, E. Non-catalytic biodiesel fuel production with supercritical methanol technologies. J. Sci. Ind. Res. 2006, 65 (5), 420-425.

(11) Yin, J. Z.; Ma, Z.; Shang, Z. Y.; Hu, D. P.; Xiu, Z. L. Biodiesel production from soybean oil transesterification in subcritical methanol with $\mathrm{K}_{3} \mathrm{PO}_{4}$ as a catalyst. Fuel 2012, 93, 284-287.

(12) Huynh, L. H.; Tran Nguyen, P. L.; Ho, Q. P.; Ju, Y. H. Catalystfree fatty acid methyl ester production from wet activated sludge under subcritical water and methanol condition. Bioresour. Technol. 2012, 123, 112-116.

(13) Basu, P. Biomass Gasification and Pyrolysis: Practical Design and Theory, 1st ed.; Elsevier: MA, 2010.

(14) Ma, L.; Wang, T.; Liu, Q.; Zhang, X.; Ma, W.; Zhang, Q. A review of thermal-chemical conversion of lignocellulosic biomass in China. Biotechnol. Adv. 2012, 30 (4), 859-873.

(15) Winsley, P. Biochar and bioenergy production for climate change mitigation. New Zealand Sci. Rev. 2007, 64, 5-10. 
(16) Eevera, T.; Rajendran, K.; Saradha, S. Biodiesel production process optimization and characterization to assess the suitability of the product for varied environmental conditions. Renew. Energy 2009, 34 (3), 762-765.

(17) Nabi, N.; Rahman, M.; Akhter, S. Biodiesel from cotton seed oil and its effect on engine performance and exhaust emissions. Appl. Therm. Eng. 2009, 29 (11-12), 2265-2270.

(18) Royon, D.; Daz, M.; Ellenrieder, G.; Locatelli, S. Enzymatic production of biodiesel from cotton seed oil using t-butanol as a solvent. Bioresour. Technol. 2007, 98 (3), 648-653.

(19) Qian, J.; Wang, F.; Liu, S.; Yun, Z. In situ alkaline transesterification of cottonseed oil for production of biodiesel and nontoxic cottonseed meal. Bioresour. Technol. 2008, 99 (18), 90099012.

(20) Chen, L.; Liu, T.; Zhang, W.; Chen, X.; Wang, J. Biodiesel production from algae oil high in free fatty acids by two-step catalytic conversion. Bioresour. Technol. 2012, 111, 208-214.

(21) Leung, D. Y. C.; Wu, X.; Leung, M. K. H. A review on biodiesel production using catalyzed transesterification. Appl. Energy 2010, 87 (4), 1083-1095.

(22) Kuwahara, Y.; Tsuji, K.; Ohmichi, T.; Kamegawa, T.; Mori, K.; Yamashita, $H$. Transesterifications using a hydrocalumite synthesized from waste slag: An economical and ecological route for biofuel production. Catal. Sci. Technol. 2012, 2 (9), 1842-1851.

(23) Boey, P. L.; Maniam, G. P.; Hamid, S. A. Performance of calcium oxide as a heterogeneous catalyst in biodiesel production: A review. Chem. Eng. J. 2011, 168 (1), 15-22.

(24) Boro, J.; Deka, D.; Thakur, A. J. A review on solid oxide derived from waste shells as catalyst for biodiesel production. Renew. Sustain. Energy Rev. 2012, 16 (1), 904-910.

(25) Wei, Z.; Xu, C.; Li, B. Application of waste eggshell as low-cost solid catalyst for biodiesel production. Bioresour. Technol. 2009, 100 (11), 2883-2885.

(26) Birla, A.; Singh, B.; Upadhyay, S. N.; Sharma, Y. C. Kinetics studies of synthesis of biodiesel from waste frying oil using a heterogeneous catalyst derived from snail shell. Bioresour. Technol. 2012, 106, 95-100.

(27) Demirbas, A. Studies on cottonseed oil biodiesel prepared in non-catalytic SCF conditions. Bioresour. Technol. 2008, 99 (5), 11251130.

(28) Schuchardt, U.; Sercheli, R.; Vargas, R. M. Transesterification of vegetable oils: A review. J. Braz. Chem. Soc. 1998, 9 (3), 199-210.

(29) Akhtar, J.; Amin, N. A. S. A review on operating parameters for optimum liquid oil yield in biomass pyrolysis. Renew. Sustain. Energy Rev. 2012, 16 (7), 5101-5109.

(30) Zhang, S.; Yan, Y.; Li, T.; Ren, Z. Upgrading of liquid fuel from the pyrolysis of biomass. Bioresour. Technol. 2005, 96 (5), 545-550.

(31) Horne, P. A.; Williams, P. T. Influence of temperature on the products from the flash pyrolysis of biomass. Fuel 1996, 75 (9), 10511059.

(32) Wang, Z.; Lin, W.; Song, W.; Wu, X. Pyrolysis of the lignocellulose fermentation residue by fixed-bed micro reactor. Energy 2012, 43 (1), 301-305.

(33) Sukiran, M. A.; Chin, C. M.; Bakar, N. K. A. Bio-oils from pyrolysis of oil palm empty fruit bunches. Am. J. Appl. Sci. 2009, 6 (5), 869-875.

(34) Shen, D. K.; Gu, S. The mechanism for thermal decomposition of cellulose and its main products. Bioresour. Technol. 2009, 100 (24), 6496-6504.

(35) Demiral, I.; Ayan, E. A. Pyrolysis of grape bagasse: Effect of pyrolysis conditions on the product yields and characterization of the liquid product. Bioresour. Technol. 2011, 102 (4), 3946-3951.

(36) Gercel, H. F. Bio-oil production from Onopordum acanthium L. by slow pyrolysis. J. Anal. Appl. Pyrolysis 2011, 92 (1), 233-238.

(37) Carrier, M.; Hardie, A. G.; Uras, U.; Gorgens, J.; Knoetze, J. Production of char from vacuum pyrolysis of South-African sugar cane bagasse and its characterization as activated carbon and biochar. J. Anal. Appl. Pyrolysis 2012, 96, 24-32. 